DOI https://doi.org/10.18551/rjoas.2016-12.27

\title{
THE REACTION OF CAPITAL MARKET TOWARDS GOVERNMENT DECISION REGARDING EXECUTION OF DRUGS CASE: A STUDY OF EXECUTION PERIOD I \& II IN 2015 AND PERIOD III IN 2016 IN INDEX LQ45 INDONESIA STOCK EXCHANGE
}

\author{
Alhamid Uswa*, Salim Ubud, Sumiati \\ Faculty of Economics and Business, University of Brawijaya, Indonesia
}

*E-mail: u2 w4@yahoo.com

\begin{abstract}
The focus of this study is about event study regarding execution of drugs cases occurred in two periods in 2015 and one period in 2016. The aim of this study is to examine whether there is empirical evidence about reaction of Indonesia capital market regarding government decision about execution in drugs cases by using abnormal return and trading volume activity indicators. Population in this study was all stocks in Indonesia Stock Exchange listing along the period of observation within index LQ45 sample. Data employed in this study consisted of daily stock price and volume of daily stock for five days before the event and five days after the event, within employing paired t-test method. This study found that there was no significant difference of average abnormal return before and after the execution in three periods of observation. On the other side, there was significant difference towards average trading volume activity before and after execution. This result explains that information about execution cannot increase the stock price and there is decrease of stock activity.
\end{abstract}

\section{KEY WORDS}

Capital market reaction, execution, abnormal return, trading volume activity.

Capital market has developed rapidly as one of supporting factors in a country economy. As one of economic instruments, one of revolution aspects in financial management is securitization which is termed as welcome for the stock (Salim, 2011) sold in the capital market. The awareness rate of capital market dynamic will increase its sensitivity; it is not only caused by micro and macro economy factors, but it can be non-economic factors, such as affairs with political background and the policy decided by government, also influence the movement of capital market. Baker and Wuger (2006) predicted that the wave of sentiment will have big impact towards market value. When the sentiment towards a country is high, obtained future return will be low and the value of the stock is pressed. In addition, the stock will show high beta sentiment (Glushkov, 2005).

Investment risk in Capital Market principally is strongly related with the occurrence of stock price volatility, where the increase and decrease of the stock one of them is influenced by information. Information bringing good news will cause the stock price increase, for example in American capital market Glodman et al. (2009) found that there is positive reaction of the stock price towards candidacy of politicians. In addition, a study done by Fisman (2001) explains that in the period of president Soeharto politic relation became valuable for the sake of keeping economy stability. Acemoglu et al. (2013) revealed a big reaction occurrence towards candidacy of financial minster Geithner in United State of America. Positive abnormal return occurs in a company which has a close relationship with Germany nationalist socialist labour party in reigning period of Hitler in 1932-1933 (Ferguson and Voth, 2008).

On the other hand, bad news will cause the decrease of stock price. Campbell et al. (2003) studied economic factors towards security of information violence reported in newspaper to public and American companies. They found negative significant reaction towards security of information related to secret data. Like the final policy of government in fighting drugs marked by the execution of drug cases perpetrators period one and two, it got big attention from society especially from investors. The activity in stock market is strongly 
influenced by the occurrence of good news whether it is just rumour or fact. Chang et al. (2012) state that the differences in information quality and law system are specific factors in a country.

In the beginning of 2015, JokoWidodo government started to affirm the decision of execution for drugs trading cases. The government did execution in three periods they are first period on $18^{\text {th }}$ January 2015 with 6 perpetrators executed, second period on $29^{\text {th }}$ April 2015 with six perpetrators executed and third period on $28^{\text {th }}$ July 2016 with four perpetrators executed. Besides Indonesian citizens, the executed perpetrators in first, second and third periods were foreigners from the Netherlands, France, Australia, Brazil, and Nigeria.

Such condition made the Netherlands government cavilled at the execution towards its citizens. In addition, France government and its citizens directly went to the field for expressing their dismissal regarding the execution. Besides, tension occurred between Indonesia and Australia since January 2015 triggered fund withdrawal of Australia from Indonesian stock market. Australia decided to withdraw their fund tremendously from the Republic of Indonesia which triggered IHSG dilution. The tension occurred in third period of execution was caused by the condition in internal country, when one of perpetrators admitted involvement of government apparatus in assisting drugs commerce. The statement created faded trust of society and investors towards policies which will be decided.

The capital market will be reacted if an event influences condition of a country. For measuring whether the reaction of the capital market exist or not towards occurred event, even study methodology was employed. Some event studies were done to analyse Indonesia stock market reaction towards economic and non-economic event. Economic event inside the country succeeded to prove that those events have relevant information content for capital market players thus the market is reacted, for example in the case of Liquidity of 16 Banks in 1997 (Manullang, 2004). In some of economic cases, there is no prove of the market reaction, for example in the case of petroleum price increase on $1^{\text {st }}$ April 2002 an the case of legitimation of Central Bank governor on 14 ${ }^{\text {th }}$ May 2003 (Manullang, 2004). Meanwhile in the case of Bali Explosion on $12^{\text {th }}$ October 2002, Indarti (2003) found the existence of significant negative abnormal return on event date as well as the difference of abnormal return average and Commerce Volume Activity between before and after the case. It tells that social-political events inside the country have role in influencing risk rate and return expectation of investor towards the fund which they have been planted in Indonesia Stock Exchange.

Based on the condition above, characteristics of information load contained in economic events can be different from information load which is contained in social, political or legal events. Thus the reaction of Indonesia capital market towards those two groups of event probably is different thus it becomes research gap in this study.

This study examined the reaction of capital market towards the decision of execution. The examination was done by employing the methodology of event study. The reaction of the market was shown by the change of related securities price before and after the execution done. The reaction can be measured by employing return and trading volume. Return is measured with the existence price change value or with employing abnormal return indicator occurred on the days around the execution of perpetrators in first, second, and third periods with the sample in this study was in total 45 companies in each research period.

Information related to the policy of death penalty with its reaction towards the capital market is rarely studied therefore the writer is interested to examine the reaction of Indonesian capital market towards government decision regarding execution of drugs cases period one and two in the year of 2015 and period three in the year of 2016. Specifically, this study aims to investigate whether (1) the execution done by the government in the first period have significant impact on the difference of Average Abnormal Return (AAR) and Average Trading Volume Activity (ATVA) in LQ45 stock in Indonesia Stock Exchange, (2) the execution done by the government in the second period have significant impact on the difference of Average Abnormal Return (AAR) and Average Trading Volume Activity (ATVA) in LQ45 stock in Indonesia Stock Exchange, and (3) the execution done by the government in the third period have significant impact on the difference of Average Abnormal Return 
(AAR) and Average Trading Volume Activity (ATVA) in LQ45 stock in Indonesia Stock Exchange.

\section{LITERATURE REVIEW}

Previous Studies. A research done by Baker, Wulger, and Yuan (2011) tested sentiment index of investor in six main stock markets. Stock markets which became the object of the research were Canada, France, Japan, Germany, England and United States of America. The research period began in 1980 until 2015. In validation test, it is found that relative sentiment has correlation with company relative price. When the sentiment is high, future profit becomes low and stock price will be suppressed. In addition, Dergiadies (2012) gave contribution in his study regarding relationship between dynamic of investor sentiment and stock return in economic market of America. Through a non-linear causal framework, the writer found that sentiment forms prediction power which has significant impact towards the stock price.

Chen and Siem (2004) in their study about terrorist, military invention and other unexpected disasters state that those things have serious implication towards the stock and obligation. The writers found that the individual stock price depicts expectation and fear of investor future, and the stock price movement can create a wave of commerce activity. The decision of buying and selling can be done fast because of panic. When information about cases such as terrorism, disaster and military invention occur, investors will run away from the market. This is because the negative sentiment from those cases.

Asteriou et al. (2000) discusses empirically the relation among stock market establishment, political instability and economy development in Greece. They measured the instability of social-politic by using time series data. Empirical result shows the existence of strong negative relation between uncertain social-political condition and general index of Athena Stock Exchange and supported theoretical hypothesis where uncertain social-political condition influence the economy development towards negative direction.

Chang et al. (2012) state that legal regulation becomes important consideration for foreign investors when they decide to invest. As the consequence, a country with good legal policy tends to attract foreign investors so is also for the other way. The writers found that global entimenthas strong impact where the capital market can be accessed more easily by foreign investors. The writers also found that strong global sentiment has relation with environment information. It means that legal aspect and environment information become main attention of investors when entering foreign investment.Strengthening or weakening both factors will influence international capital flow.

Brzeszyński, J. et al. (2015) studied about reaction and sentiment of investors responding towards public information issued by developing countries. Public information issued consisted of monetary policy announcement, news related to IMF and political news. The finding about investors sentiment was adequately various. Though there was evidence stating that individual investor sentiment has impact towards stock return cross-sectionally, other findings confirmed that securities return volatility in developing countries market was influenced by variable of global and local markets sentiment. In addition, based on some findings, portfolio result was influenced by sentiment proxy of investor which also influenced commerce frequency and IPO decision.

Solakoglu and Demir (2014) investigated that issued news has influence towards profit volatility in Istanbul Stock Exchange. Issued news can be seen through many headlines appeared in daily news. They found that the issued news mostly caused the decrease in profit volatility.

Ahmed and Hussain (2014) tested how political and military news have impact towards profit and volatility in stock exchanges of India and Pakistan. By employing data from January 1997 until December 2008, they found that military news come from rival country resulted in significant reaction in both countries stock exchanges.

A study was done by Beverley (2007) entitled Stock Market Event Studies and Competition Commission Inquiries. This study has event study format and cumulative 
abnormal return (CAR) methodology. But the result of this study does not find significant abnormal return in the event period. A study done by Obi, Surujlal and Okubena (2010) entitled South African Equity Market Reaction to the World Cup Announcement tested the impact of South Africa as the World Cup 2010 hosting country announcement towards abnormal return obtained in South Africa Stock Exchange. This study employed Market Model methodology. The result shows that significant market reaction towards the event.

Abnormal Return. Abnormal return is an indicator which can depict the effect of an event or information. Abnormal return is difference between actual return and return, where expected return is return which is expected from done investment (Jogiyanto, 2003). Brown and Walner (1985) state that expected return can be estimated using some models they are Mean Adjusted Model which considers expected return with constants value is same with previous average of realization return along estimated period. Market model is expected return calculation by using model market which is done in two steps they are forming expected model by employing realization data along estimated period and employing expected model to expect the expected return in window period. Meanwhile, Market Adjustment Model considers that the best predictor for estimating a securities return is market index return at that time. By employing this model, estimated securities return is considered as same as stock index return.

It can be concluded that the mention condition above happened because of an event such as social, political, and economic events. It can create an abnormal movement thus change of trend can be seen around the date of announcement. The change of higher abnormal return value before the date of announcement indicates that information announcement gives positive reaction towards the market and showing new balance price influenced by the event. In calculating the return some indicators which are usually employed are Average Abnormal Return and Cumulative Abnormal Return.

Trading Volume Activity (TVA). Trading volume activity is overall buying and selling transaction value of stock done by investor in a currency (Sutrisno, 2000). The increase of trading volume activity and the increase of price are stronger indication of a bullish condition.

Trading volume activity or TVA is employed to measure whether individual investors know the information issued by a company and use it in buying or selling stock, thus they will get profit from the abnormal return. The mentioned stock is usual stock that sold in Indonesia capital market, especially in Indonesia Stock Exchange. Trading Volume Activity is an instrument which can be employed to see the capital market reaction towards information through parameter of selling volume activity movement in capital market.

Selling volume is a depiction of buying interest intensity and pressure behind occurred value of price movement. The activity of stock trading can be seen through indicator of trading volume activity. The tremendous activity of trading in stock exchange will be interpreted as a sign of more favourable market so is the other way. Active trading stock certainly has big volume activity and big volume stock will create high return (Chordia, et al., 2000).

\section{HYPOTHESIS AND METHODS OF RESEARCH}

On $18^{\text {th }}$ January 2015 , execution was done towards six perpetrators of drugs cases. One prisoner was an Indonesian meanwhile other six prisoners were foreigners. Two of them were the Netherlands and Brazil citizens. This execution was the first period. The Netherlands has omitted death penalty since 1983. Thus, the condition above created sentiment from the mentioned country towards the execution policy. In addition, a Brazilian media, Folha de Sao Paulo, the Brazilian would be the first Brazilian executed. The impact is, Brazilian and the Netherlands governments withdrew their ambassadors. Brazil asserted that the execution would have impact towards the bilateral relationship of the two countries. The Netherlands also called back its ambassador in Jakarta and strongly cavilled execution towards its citizen. Therefore the first hypotheses proposed in this study are:

H1a: significant difference of average abnormal return occurred on the day before and after the first execution done. 
$H 1 b$ : significant difference of average trading volume occurred on the day before and after the first execution done.

In the second period done on $29^{\text {th }}$ April 2015 execution was done towards eight prisoners, consisted of four Nigerian, two Australian, a Brazilian, and an Indonesian. Tension occurred between Indonesia and Australia since January 2015, a little bit triggered Australian fund withdrawal from Indonesian stock market. Australia, one of 10 biggest investors for Indonesia decided to withdraw their fund tremendously from the Republic of Indonesia which finally triggered the IHSG dilution. The second hypotheses proposed for this study are:

H2a: significant difference of average normal return occurred on the day before and after the second execution.

$H 2 b$ : significant difference of average trading volume occurred on the day before and after the second execution done.

After a year, on $28^{\text {th }}$ July 2016 , execution was done towards ten foreigners and four Indonesians. Tension occurred in this execution was related towards internal of the country, when one of the perpetrators admitted the involvement of government apparatus in assisting drugs trading. The issue created lack of trust from society and market players towards future policies that will be taken. Therefore, the third hypotheses proposed in this study are:

$H 3 a$ : significant difference of average normal return occurred on the day before and after the third execution done.

$H 3 b$ : significant difference of average trading volume occurred on the day before and after the third execution done.

The population in this study was entered stocks in LQ45 registered in Indonesia Stock Exchange in the period of August 2014 - January 2015 for the first event and the period of February 2015 - July 2015 for the second event and the period of February 2016 - August 2016 for the third period. The sample taken was 45 companies in index LQ 45 which are registered in Indonesia Stock Exchange. The writer employed the data in those two periods because those periods depict the event of execution which occurred in first, second, and third periods.

A method employed in calculating abnormal return was market model by deciding the period of observation. The period for observation was 10 days around the announcement of execution, 5 days before the announcement marked by -5 until -1 meanwhile 5 days after the announcement marked by +1 until +5 . Besides abnormal return, reaction of the market can also be searched trading volume activity indicator.

Calculating Abnormal Return of Each Stock (Jogiyanto, 2003):

$\mathbf{A R}_{\mathrm{t}} \quad=\mathbf{R}_{\mathrm{t}}-\mathbf{E}\left(\mathbf{R}_{\mathrm{t}}\right)$

Notes: $A R_{i t}=A b n o r m a l$ return of the stock $i$ on the day $t ; R_{i t}=$ Actual return of the stock $i$ on the day $t$; $E\left(R_{i t}\right)=$ Expected return of the stock I on the day $t$.

Calculating Trading Volume Activity (Jogiyanto, 2003):

\section{TVA $=\quad \frac{\sum \Sigma \text { Stock i traded at the t time }}{\Sigma \text { stock icycled at the t time }}$}

Notes: TVA $=$ Trade volume activity of the stock.

Analysis of Significance T-Testing (on $\alpha=5$ ):

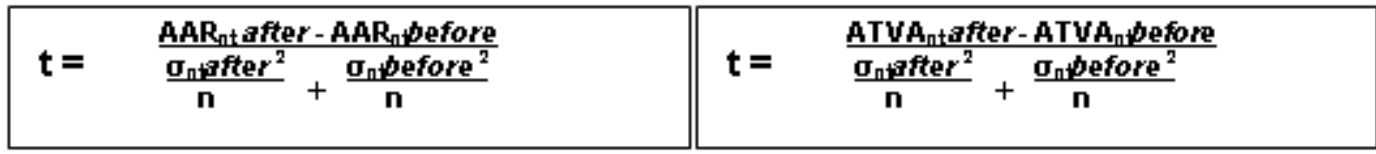

Notes: $\mathrm{T}=$ difference testing; $\mathrm{AAR}=$ Average Abnormal Return; ATVA $=$ Average Trading Volume Activity; $\sigma_{\mathrm{nt}}=$ Deviation Standard. 


\section{RESULTS OF RESEARCH}

The analysis of statistic descriptive towards lowest abnormal return variable occurred in the second period showed the value -1.322 meanwhile the highest value of abnormal return in the execution event occurred in the third execution with the value 0.0160 . The average of highest abnormal return occurred in the third execution with the value 0.0032 and the lowest occurred in the second execution with the value -1.2295 .

The lowest value of Trading Volume Activity on the execution of happened in the third period with the value 0.0015 , meanwhile the highest value of Trading Volume Activity in the execution occurred in the first period of the execution with the value 0.0039 . The highest average of Trading Volume Activity occurred in the first period of the execution with the value 0.0025 and the lowest occurred in the third period of the execution with the value 0.0021 .

The First Period of the Execution (Hypotheses testing of 1a and 1b). Average normal return got increase in the first period of the execution from 0.00237 added becomes 0.00564 . The rate of significance for testing Abnormal Return employed probability of $5 \%$ or 0.05 . If the value of two-tail significance is $<0.05$, then significant abnormal return exists, so is the other way. From the result of calculation, it was found that the value of two-tail significance is 0.33004 meaning it is higher than 0.05 . It means that significant abnormal return did not occur around the time the first execution was held. In the first period, the absolute score of $t$ count is 1.10790 where this result is lower if it is compared with the score of $t$ table which has 2.77645. Thus, hypothesis 1a which states that significant difference of average normal return occurred before and after the first execution is denied.

Average trading volume activity in the first period of the execution got increase from 0.0020419 added becomes 0.0033028 . The rate of significance to test trading volume activity employed the probability of $5 \%$ or 0.05 . If the score of two-tail significance is $<0.05$, it means significant trading volume activity exists, so is the other way. From the calculation result, it is found that the two-tail significance score is 0.0142608 or lower than 0.05 . It means that significant trading volume activity occurred in the first period of the execution. In the first period, the absolute score of $t$ count is 4.1499595 where the result is higher if it is compared with the score of $t$ table which is 2.77645 . Therefore, the hypothesis $1 \mathrm{~b}$ which states that significant average trading volume activity occurred before and after the first period of execution is accepted.

Table 1 - AR and TVA Difference Testing in the First Period

\begin{tabular}{|c|c|c|c|c|}
\hline \multirow{2}{*}{$\mathrm{t}$-Test: Paired Two Sample for Means } & \multicolumn{2}{|c|}{ AR1 } & \multicolumn{2}{|c|}{ TVA1 } \\
\hline & Before & After & Before & After \\
\hline Mean & -0.00237 & 0.00564 & 0.0020419 & 0.0033028 \\
\hline Variance & 0.00009 & 0.00017 & 0.0000002 & 0.0000007 \\
\hline Observations & 5 & 5 & 5 & 5 \\
\hline Pearson Correlation & \multicolumn{2}{|c|}{-0.03257} & \multicolumn{2}{|c|}{0.6172793} \\
\hline $\mathrm{Df}$ & \multicolumn{2}{|c|}{4} & \multicolumn{2}{|c|}{4} \\
\hline t Stat & \multirow{2}{*}{\multicolumn{2}{|c|}{$\begin{array}{r}-1.1079 \\
0.16502\end{array}$}} & \multirow{2}{*}{\multicolumn{2}{|c|}{-4.1499595}} \\
\hline $\mathrm{P}(\mathrm{T}<=\mathrm{t})$ one-tail & & & & \\
\hline t Critical one-tail & \multicolumn{2}{|c|}{2.13185} & \multicolumn{2}{|c|}{2.1318468} \\
\hline $\mathrm{P}(\mathrm{T}<=\mathrm{t})$ two-tail & \multicolumn{2}{|c|}{0.33004} & \multicolumn{2}{|c|}{0.0142608} \\
\hline t Critical two-tail & \multicolumn{2}{|c|}{2.77645} & \multicolumn{2}{|c|}{2.7764451} \\
\hline
\end{tabular}

The Second Period of the Execution (Hypothesis testing of $2 a$ and $2 b$ ). Average normal return in the second period of the execution got decrease from -0.00879 becomes -0.26141 . The rate of significance for testing Abnormal Return employed probability of $5 \%$ or 0.05 . If the value of two-tail significance is $<0.05$, then significant abnormal return exists, so is the other way. From the calculation result, two-tail significance score was obtained which is 0.4003 and higher than 0.05 . It means that significant average normal return did not occurred in the second period of the execution. In the first period, the absolute score of $t$ count is 0.9403 where the result is lower if it is compared with t table score which is 2.7764 . 
Therefore, the hypothesis $2 a$ which states significant difference of the average normal return occurred before and after the first period of the execution is denied.

Average trading volume in the second period of the execution got increase from 0.00190 added becomes 0.00257 . The significance rate for testing trading volume activity employed the probability of $5 \%$ or 0.05 . If the score of two-tail significance is $<0.05$, it means significant trading volume activity exists, so is the other way. From the calculation result, twotail significance score obtained is 0.00027 which is lower than 0.05 . It means that significant trading volume activity occurred around the time when the second execution was done. In the first period, the absolute score of $t$ count is 3.62442 where the result is higher if it is compared with the score of $t$ table which is 2.77645 . Therefore, the hypothesis $2 b$ which states significant different of average trading volume occurred before and after the second period of the execution is accepted.

Table 2 - AR and TVA Difference Testing in the Second Period

\begin{tabular}{|c|c|c|c|c|}
\hline \multirow{2}{*}{ t-Test: Paired Two Sample for Means } & \multicolumn{2}{|c|}{ AR2 } & \multicolumn{2}{|c|}{ TVA2 } \\
\hline & Before & After & Before & After \\
\hline Mean & -0.00879 & -0.26141 & 0.0019 & 0.00257 \\
\hline Variance & 0.00025 & 0.35168 & 0 & 0 \\
\hline Observations & 5 & 5 & 5 & 5 \\
\hline Pearson Correlation & \multicolumn{2}{|c|}{-0.47463} & \multicolumn{2}{|c|}{-0.46556} \\
\hline $\mathrm{Df}$ & \multicolumn{2}{|c|}{4} & \multicolumn{2}{|c|}{4} \\
\hline t Stat & \multicolumn{2}{|c|}{0.9403} & \multicolumn{2}{|c|}{-3.62442} \\
\hline $\mathrm{P}(\mathrm{T}<=\mathrm{t})$ one-tail & \multicolumn{2}{|c|}{0.2002} & \multicolumn{2}{|c|}{0.01113} \\
\hline t Critical one-tail & \multicolumn{2}{|c|}{2.1318} & \multicolumn{2}{|c|}{2.13185} \\
\hline $\mathrm{P}(\mathrm{T}<=\mathrm{t})$ two-tail & \multicolumn{2}{|c|}{0.4003} & \multicolumn{2}{|c|}{0.02227} \\
\hline t Critical two-tail & \multicolumn{2}{|c|}{2.7764} & \multicolumn{2}{|c|}{2.77645} \\
\hline
\end{tabular}

The Third Period of the Execution (Hypotheses testing of $3 a$ and 3b). Average abnormal return in the third period of the execution got decrease from 0.00381 becomes 0.00242 . The rate of significance for testing Abnormal Return employed probability of $5 \%$ or 0.05 . If the value of two-tail significance is $<0.05$, then significant abnormal return exists, so is the other way. From the calculation result, two-tail significant score obtained is 0.87665 which is higher than 0.05 . It means that the significant average normal return did not occur in the second period of the execution. In the first period, the absolute score of $t$ count is 0.16404 where this result is lower if it is compared with the score of $t$ table which is 2.7764. Therefore, the hypothesis $3 a$ which states that the significant difference of average normal return occurred before and after the third period of the execution is denied.

Table 3 - AR and TVA Difference Testing in the Third Period

\begin{tabular}{|c|c|c|c|c|}
\hline \multirow{2}{*}{ t-Test: Paired Two Sample for Means } & \multicolumn{2}{|c|}{ AR3 } & \multicolumn{2}{|c|}{ TVA3 } \\
\hline & Before & After & Before & After \\
\hline Mean & 0.00381 & 0.00242 & 0.002 & 0.00231 \\
\hline Variance & 0.00003 & 0.00021 & 0 & 0 \\
\hline Observations & 5 & 5 & 5 & 5 \\
\hline Pearson Correlation & \multicolumn{2}{|c|}{-0.81963} & \multicolumn{2}{|c|}{0.90821} \\
\hline $\mathrm{Df}$ & \multicolumn{2}{|c|}{4} & \multicolumn{2}{|c|}{4} \\
\hline t Stat & \multirow{2}{*}{\multicolumn{2}{|c|}{$\begin{array}{l}0.16404 \\
0.43883\end{array}$}} & \multirow{2}{*}{\multicolumn{2}{|c|}{$\frac{-2.50243}{0.0333}$}} \\
\hline $\mathrm{P}(\mathrm{T}<=\mathrm{t})$ one-tail & & & & \\
\hline t Critical one-tail & \multicolumn{2}{|c|}{2.13185} & \multicolumn{2}{|c|}{2.13185} \\
\hline$P(T<=t)$ two-tail & \multicolumn{2}{|c|}{0.87765} & \multicolumn{2}{|c|}{0.06659} \\
\hline t Critical two-tail & & \\
\hline
\end{tabular}

Average trading volume activity in the third period of the execution got a little increase from 0.00200 added becomes 0.00231 . The significance rate for testing trading volume activity employed the probability of $5 \%$ or 0.05 . If the score of two-tail significance is $<0.05$, it means significant trading volume activity exists, so is the other way. From the calculation result, two-tail significant score obtained is 0.06659 which is higher than 0.05 . It means that 
significant average trading volume activity did not occur around the time when the third period of the execution was done. In the first period, the absolute score of t count is 2.50243 where this result is lower if it is compared with the score of $t$ table which is 2.77645 . Therefore, the hypothesis $3 \mathrm{~b}$ which states that significant difference of average trading volume activity occurred before and after the third period of the execution is denied.

\section{DISCUSSION OF RESULTS}

Principally, execution is not good news because it is collided with the human rights for living. But on the other side, the first period of the execution was required to give wary effect towards done crimes. Indonesia, which now becomes the target for drugs trafficking continue gives effort for fighting and giving wary effect for the perpetrators of drugs cases by implementing death penalty. The announcement of the government to enforce the first execution of drugs cases caused the activity of stock trading fluctuated which tend to lead towards selling direction causing the decrease of stock prices thus investors did not get profit from the event.

In the second execution, it can be seen the relevance between capital market and the drugs business. Capital market which is alternative media for investment, utilized by perpetrators of drugs business for doing money laundering for spinning the money flow towards the profit which can be obtained from the illegal business. Thus execution occurred towards the perpetrators would have impact towards the decrease of securities demand which exists in capital market and the impact of the decrease demand made the investors in capital market did not get the abnormal return from the event.

In the third execution, the execution done was not without reason because punishment in jail still gives the perpetrators freedom in to do drugs transaction. The existence of this freedom cannot be separated from the involvement of authorities, because basically the drugs business is an illegal business with big profit. The decrease of society trust towards the involved authorities also caused the decrease of buying activities in capital market thus the stock prices did not increase.

Therefore, Indonesian government does not need to be apprehensive in considering the decision of the death penalty for the drugs trafficking cases. According to the head of National Anti-Narcotics Agency (in Bahasa is BadanNarkotikaNasional/BNN) Police Commissioner General Budi Waseso, Indonesia is the biggest narcotics segment market in Asia, moreover now included in narcotics producer country. In addition, from all correctional facilities (in Bahasa is LembagaPemasyarakatan/LP) in Indonesia, about 60 per cent of the prisoners are drugs perpetrators. Similar statement was also stated by public relation ambassador of Aceh Regional Police, Fauziah Aida who stated that Aceh still becomes one of the biggest marijuana producersin South East Asia where in Aceh the plant grows widely and it supported by the climate and land condition which make the plant grows prosperously even without agriculture method. Thus, the firmness of Indonesian government to fight narcotics until the roots requires real action which one of them is death penalty thus Indonesia will be free from narcotics.

Implication of the Result of the Study. Implication from the result of the study covers two things they are theoretical and practical implications. Theoretical implication is related to its contribution for the development of financial management theories regarding study event and practical implication is related to the result of the study contribution towards the implementation of death penalty in Indonesia. Theoretical implication of this study is related to Behavioural Finance Theory and Signalling Theory. Behavioural Finance Theory explains investor's behaviour which influences the process of decision making in investing the fund in capital market. Besides, signalling theory explains that every decision which is announced to public will bring signal to the market. The signal can create both positive and negative respond. From the result of consistently done study, it is shown that death penalty towards crime perpetrators in this case are narcotics perpetrators was responded by investors as bad news especially for some investors who aims for many laundering. 
Practical implication of this study is related to related parties such as, investors, LQ45 issuers and the government. This study gives the description of the result of the study which enables investors to notice the signal towards announced event and to make the investors having wait and see attitude towards a short period event. For LQ45 issuers, it is important to make it still stable in keeping its financial performance, thus if non-economic cases occurred, they will not influence the companies in the future. Meanwhile the government here as authority party in making decision if death penalty, does not have to be loose towards political and legal pressures whether from internal of the country or external of the country.

\section{CONCLUSION}

Some conclusions that can be withdrawn from this study are:

1. In the first period of the execution, the reaction of the market showed that there was no meaningful change in the respond of the market on the abnormal return between before and after the execution. It means that the death penalty announcement has no meaningful information for investors. On the other side, the existence of the difference on the trading volume activity before and after the execution is caused by the attitude of wait and see of the investors.

2. In the second period of the execution, abstain of abnormal return indicated that the investors tended to be careful in responding towards the execution decision because the existence of economic and political pressures from some countries which oppose the execution. On the other hand, significant difference occurred in trading volume activity was caused by wait and see attitude of the investors.

3. In the third period of the execution, the decrease of trust from the society towards the authorities which were assumed to involve in narcotics business caused the decrease of trading activity in the capital market thus the stock price also has no increase which caused the investors did not abnormal return.

\section{REFERENCES}

1. Acemoglu, D., Johnson, S., Kermani, A., Kwak, J., \& Mitton, T. 2013. The value of connections in turbulent times: Evidence from the United States. Mimeo, MIT.

2. Ahmed, A., and Hussain, S.M. 2014. The financial fost of rivalry: A tale of two south Asia neighbors. Emerging Markets Finance and Trade, 50,35-60.

3. Asteriou, D., \& Siriopoulos, C. 2000. The role of political instability in stock market development and economic growth: The case of Greece. Economic Notes, 29(3), 355374.

4. Baker, M., \& Wurgler, J. 2006. Investor sentiment and the cross-section of stock returns. Journal of Finance, 61, 1645-1680.

5. Baker, M., Wurgler, J., \& Yuan, Y. 2011. Global, local and contagious investor sentiment, Journal of financial economics.

6. Beverley, L. 2008. Stock market event studies and competition commission inquiries.

7. Brown, S.J., \& Warner, J.B. 1985. Using daily stock returns: the case of event studies. J. Financ. Econ. 14, 3-31.

8. Brzeszczyński, J., Gajdka, J., \& Kutan, A.M. 2015. Investor response to public news, sentiment and institutional trading in emerging markets: A review. International Review of Economics \& Finance, 40, 338-352.

9. Cam, M.A. 2007. The Impact of Terrorist Attacks on Financial Markets (Doctoral dissertation, RMIT University).

10. Campbell, K., Gordon, L.A., Loeb, M.P., and Zhou, L. 2003. The economic cost of publicly announced information security breaches: empirical evidence from the stock market. Journal of Computer Security, 11(3), 431-448.

11. Chang, Y.Y., Faff, R., and Hwang, C.-Y. 2012. Local and global sentiment effects, and the role of legal, information and trading. (Available at SSRN: http://ssrn.com/abstract=1800550 or http://dx.doi.org/10.2139/ssrn.1800550) 
12. Chen, A.H, Siems, T.F. 2004. The Effects of Terrorism on Global Capital Markets. European Journal of Political Economy, 20, 349-366.

13. Chordia, T., Roll, R., \& Subrahmanyam, A. 2011. Recent trends in trading activity and market quality. Journal of Financial Economics, 101(2), 243-263.

14. Dergiades, T. 2012. Do investors' sentiment dynamics affect stock returns? Evidence from the US economy. Economics Letter.

15. Ferguson, T., \& Voth, H.J. 2008. Betting on Hitler - the value of political connections in Nazi Germany. Q. J. Econ. 123, 101-137.

16. Fisman, R. 2001. Estimating the value of political connections. Am. Econ. Rev. 91,10951102.

17. Glaser, M., \& Weber, M. 2009. Which past returns affect trading volume? Journal of Financial Markets, 12(1), 1-31.

18. Glushkov, D., 2005. Sentiment Betas. Unpublished working paper, University of Texas, Austin.

19. Goldman, E., Rocholl, J., So, J. 2009. Do politically connected boards affect firm value? Rev. Finance. Stud. 22, 2332-2360.

20. Indarti, J. 2003. Analisis Perilaku Return dan Aktivitas Volume Perdagangan Saham di Bursa Efek Jakarta (Event Study: Dampak Peristiwa Bom Bali Tanggal 12 Oktober 2002 pada Saham LQ 45). Magister of Management University of Diponegoro, Semarang.

21. Jogiyanto H.M. 2003. Teori Portofolio dan Analisis Investasi. BPFE.

22. Manullang, T.L.A. 2004. "Analisis Efisiensi Pasar Modal Indonesia Menggunakan Pendekatan Multiple Event Sosial \&Politik dan Ekonomi. Unpublished Dissertation, Doctoral Program Economic Sciences University of Persada Indonesia YAI, Jakarta.

23. Obi, P., Surujlal, J., \& Okubena, O. 2009. South African equity market reaction to the 2010 FIFA World CupTM announcement. African Journal for Physical, Health Education, Recreation and Dance, 15(4).

24. Salim, U. 2011. Manajemen Keuangan Strategik. Malang: UB Press.

25. Sutrisno. 2000. Manajemen Keuangan (EdisiSatu). Yogyakarta: Ekonisia.

26. Tandelilin, E. 2010. Portofolio dan Investasi Teori dan Aplikasi: Edisi Pertama. Yogyakarta: Kanisius. 